Journal of the Egyptian Society of Parasitology, Vol.43, No.1, April 2013

J. Egypt. Soc. Parasitol., 43(1), 2013: 245 - 258

\title{
DIGESTIVE ENZYME AS BENCHMARK FOR INSECTICIDE RE- SISTANCE DEVELOPMENT IN CULEX PIPIENS LARVAE TO CHEMICAL AND BACTERIOLOGIC INSECTICIDES
}

\section{By}

\section{NASHWA H. KAMEL ${ }^{1}$, IMAN M. BAHGAT ${ }^{2}$ and GAMAL A. EL KADY ${ }^{3}$}

Heart and Specialized Surgery Hospital, Ain Shams University ${ }^{1}$ Cairo, Faculty of Education ${ }^{2}$, and Department of Plant Protection, Faculty of Agriculture $^{3}$, Suez Canal University, Port Said ${ }^{2}$ and Ismailia ${ }^{3}$, Egypt

\begin{abstract}
This work monitored changes in some digestive enzymes (trypsin and aminopeptidase) associated with the building up of resistance in Cx. pipiens larvae to two chemical insecticides (methomyl and/or malathion) and one biological insecticide (Bacillus thuringiensis-H14 or B.t $\mathrm{H} 14$ ).

The $\mathrm{LC}_{50}$ value of methomyl for both field and the $12^{\text {th }}$ generation $(\mathrm{F} 12)$ of the selected strain was $1.789 \mathrm{ppm}$ and $8.925 \mathrm{ppm}$ respectively. The $\mathrm{LC}_{50}$ value of malathion for both field and the F12 of the selected strain was $0.082 \mathrm{ppm}$ and 0.156 ppm respectively, and those of $B . t \mathrm{H} 14$ of field strain and the F12 was $2.550 \mathrm{ppm} \&$ $2.395 \mathrm{ppm}$ respectively.

The specific activity of trypsin enzyme in control susceptible colony was $20.806 \pm 0.452 \mu \mathrm{mol} / \mathrm{min} / \mathrm{mg}$ protein; but at $\mathrm{F} 4$ and $\mathrm{F} 8$ for malathion and methomyl treated larvae were $10.810 \pm 0.860 \& 15.616 \pm 0.408 \mu \mathrm{mol} / \mathrm{min} / \mathrm{mg}$ protein, respectively. Trypsin activity of F12 in treated larvae with B.t.H14 was $2.097 \pm 0.587 \mu \mathrm{mol} / \mathrm{min} / \mathrm{mg}$ protein. Aminopeptidase specific activity for susceptible control larvae was $173.05 \pm 1.3111 \mu \mathrm{mol} / \mathrm{min} / \mathrm{mg}$ protein. This activity decreased to $145.15 \pm 4.12^{*}, 152.497 \pm 6.775 \& 102.04 \pm 3.58^{\mathrm{a}} \mu \mathrm{mol} / \mathrm{min} / \mathrm{mg}$ protein after larval (F12) treatment with methomyl, malathion and B.t H14 respectively.

Key Words: Egypt, Culex larvae, Methomyl, Malathion, Bacillus thuringiensisH14, Proteolytic enzymes, Trypsin, Aminopeptidase.

\section{Introduction}

Vector-borne diseases affect two thirds of the world's population and kill millions annually. The cost of combating these diseases and loss of productivity has crippled the economic growth of endemic countries (Riehle and Jacobs-Lorena, 2005). In Egypt, insectvectors of diseases constitute a health,

veterinary and economic problems (Morsy, 2012), particularly mosquitoes (Mikhail et al, 2009). In Egypt Culex mosquito is the major vector of bancroftian filariasis (Bahgat et al, 2011), Rift Valley virus (Hanafi et al, 2011) West Nile virus (El-Bahnasawy et al, 2013) and others. On the other hand, the intensive use of chemical insecti-
\end{abstract}


cides as (organophosphorous and carbamate) to achieve control of the pests in agriculture and vectors control has been widely used for the past 20 years led to the development of resistant insect populations (Mostafa and Allam, 2001). Insect populations may survive under the effect of toxic chemical compounds by different physiological mechanisms, including increased metabolism of the pesticide to nontoxic products, decreased target site sensitivity, decreased rates of insecticides penetration, and increased rates of insecticide excretion (Hemingway and Karunaratne 1998; Martinez-Torres et al, 1998; Brooke et al, 1999)

\section{Materials and Methods}

The immature stages of $C x$. pipiens were collected from El Moassasa, Cairo Governorate. This area was characterized by large green agricultural fields, drainage canals and irrigation ducts used in agriculture. El-Moassasa is about $7 \mathrm{Km}$ far from Qalyobia Governorate and $20 \mathrm{Km}$ from Giza Governorate.

Mosquito rearing: The collected larvae were maintained in standardized laboratory conditions in walk-in insectaries (Harbach, 1988; Timmermann and Briegel, 1993), at the Research and Training Center on Vectors of Diseases, Faculty of Science, Ain Shams University; till adult emergence. The adult mosquitoes resulting from one egg raft (from the field) reared in the laboratory for 15 successive generations under identical laboratory conditions, without being exposed to insecticide to raise their susceptibility (Shoukry et al, 1990). Emerging adults were provided daily with $10 \%$ glucose solution and supplied with small water containers for egg laying. For oviposition; four days old adults were deprived from food for $24 \mathrm{~h}$, and then allowed to feed on a pigeon. Each egg raft was placed in a plastic cup containing tap water for hatching. This technique was used through all experiments.

Culex pipiens colonized in the laboratory were employed in this study. The larvae resulting from the eggs lay by the $15^{\text {th }}$ generation females (pure parental colony), Colony were divided into four groups. Three of them were subjected to selection pressure by chemical and/or biological insecticides; the fourth was cultured without exposure to any insecticide and used as the susceptible control laboratory strain.

Insecticides: Two chemical insecticides, methomyl (Lannate $90 \% \mathrm{SP}$, is one of oxime carbamate insecticides), malathion $57 \%$ (is one of the most important insecticides in the class of phosphorothiolothionate) and one biological insecticides Bacillus thuringiensis (B. t. H14) have been used. All insecticide tests were carried out to establish line parameters of log concentration-probit response lines (Ld-p lines) by using five to six dosages of the insecticide within the range producing 5-95\% mortality.

Insecticides preparation for bioassay and resistance development (selected strain):

a- Malathion solution were made in ethyl alcohol $(95 \%)$ and stored at $4{ }^{\circ} \mathrm{C}$ 
for less than 2 month. Methomyl was dissolved in distaled water and used fresh. Series of methomyl and malathion concentrations were added to disposable paper cups, each containing $100 \mathrm{ml}$ of distilled water and twenty late 3 rd instar mosquito $C x$. pipiens larvae.

b- B. $t$. H14 was suspended as $100 \mathrm{mg}$ technical powder of in $10 \mathrm{ml}$ distilled water by vigorous shaking to ensure the homogeneity of the $1 \%(\mathrm{w} / \mathrm{v})$ suspension, which was then diluted serially 10 folds in amounts of $10 \mathrm{ml}$, the suspensions with concentrations of 0.1 , $0.01,0.001$ and $0.0001 \%$ were made.

All materials were freshly prepared ones. The needed aliquots of the diluted suspensions were added to cups containing $100 \mathrm{ml}$ distilled water and containing twenty late $3^{\text {rd }}$ instar larvae.

For both chemical and biological insecticides, the test was set up by using 5 concentrations yielding 10-95\% mortality with 3 replicates for each concentration for each strain (field, laboratory strain and selected group). Three cups were left untreated as control. The controls were made with $1 \mathrm{ml}$ of ethanol for the chemical insecticides and $1 \mathrm{ml}$ distilled water for the biological insecticide. The mortality was recorded at $24 \mathrm{~h}$ and $48 \mathrm{~h}$, after treatment with chemical and/or biological insecticides, the moribund larvae were considered as dead. Lethal concentrations for $50 \%$ mortality levels, 95\% confidence limit (C. 1.) of LC50 values, chi-square, and Ld-p lines were determined by using a probit analysis computer program.
Bioassays performed on $3^{\text {rd }}$ instar larvae from both the field strain and the parental generation (larvae of the $15^{\text {th }}$ generation) by standard larval susceptibility test (WHO, 1981). The resistance development experiments were carried out after Rodcharoen and Mulla (1994).

The selected lines with chemical and biological insecticides were subjected to selection pressure starting in F1 generation. The third instar larvae were treated with serial dilutions of methomyl, malathion and/or (B. t. H14) to detect the concentration that yield 50\% mortality $\left(\mathrm{LC}_{50}\right)$ for $24 \mathrm{hrs}$ after exposure to the chemical insecticides and for $48 \mathrm{~h}$ in case of the B.t. H14. The methomyl, malathion, B.t. H14 and the control lines were tested every two generations using standard bioassay techniques, (continuous selection pressure extended for 12 generations).

If the susceptibility level of any selected line changed, new $\mathrm{LC}_{50}$ values were used in the selection of the succeeding generation.

All biochemical assays were done in Faculty of Agriculture, Ismailia, Suez Canal University. Biochemical assays were undertaken to evaluate the behavioral activities of midgut digestive enzymes (trypsin and aminopeptidase) in Cx. pipiens larvae under stress conditions (application with some chemical and biological insecticides).

Total protein determination in larvae (Protein assay): Total protein content (protein concentration) of the samples (enzyme preparations supernatant) was determined from an aliquot using, the 
Bio-Rad Protein Assay derived from the Commassie Brilliant Blue dye G250 method of Bradford (1976) as modified by Spector (1978). Bovine serum albumin (BSA) was used as the standard protein. Enzyme activities are expressed in units of $\mu \mathrm{mol} / \mathrm{min}$ and are presented as the specific activities ( $\mu \mathrm{mol} / \mathrm{min} / \mathrm{mg}$ protein)

Proteolytic enzymes: The activities of trypsin and aminopeptidase in whole Cx. pipiens larvae were determined using synthetic peptide substrates. The cleavage of such substrates results in release of colored products ( $p$-nitroanilide). The absorption of $p$-nitroanilide, was automatically measured at wave length $405 \mathrm{~nm}$ by using ELISA reader.

Samples preparation: For microplate trypsin assays, two larvae were homogenized in $400 \mu \mathrm{l}$ PBS $(0.01 \mathrm{M}, \mathrm{pH}$ 7.2) and spun at $10,000 \mathrm{~g}$ for $8 \mathrm{~min}$ at $4^{\circ} \mathrm{C}$, and the supernatant containing enzymes was used in the assays, $50 \mu 1$ were added to a microplate well.

Trypsin assay: $4 \mathrm{mM} \mathrm{N} \alpha$-benzoylDL-arginine-p-nitroanilide (BApNA) in $7 \%$ DMF was diluted with $50 \mathrm{mM}$ Trizma hydrochloride (Tris hydroxymethyl) aminomethane hydrochloride, $\mathrm{pH} 8.5$ ), and $50 \mu \mathrm{l}$ were added to each well (final BApNA concentration was $2 \mathrm{mM}$ ). After $60 \mathrm{~min}$ at $37^{\circ} \mathrm{C}$ absorbance was monitored (Ramasamy et al, 1996).

Aminopeptidase assay: $3 \mathrm{mM} \mathrm{L}-$ leucine $p$-nitroanilide (L $p \mathrm{NA}$ ) in $3 \%$ DMSO was diluted with $50 \mathrm{mM}$ Tris$\mathrm{HCL}$ at $p \mathrm{H} 8.5$ to the desired concentration (Dillon and Lane, 1993) and
$50 \mu 1$ were added to each well (final $\mathrm{L} p \mathrm{NA}$ concentration was $1.5 \mathrm{mM}$ ). Absorbance values were read after $15 \mathrm{~min}$ at $37^{\circ} \mathrm{C}$.

For both aminopeptidase and trypsin, the absorbance values of blanks were measured and subscript from the sample reading. The amount of nitroanilide were calculated from standard curves of p-nitroanilide and the results were converted to micromoles $/ \mathrm{min} / \mathrm{mg}$ of protein.

\section{Results}

The results are shown in tables $(1,2$, $3 \& 4$ )

The $C x$. pipiens mosquito larvae were artificially selected for two chemical (methomyl and malathion) and one biological (B. t. H14) insecticides. The susceptibility of the third larval instars to the three insecticides was measured every two generations using contact bioassays.

For methomyl and malathion, the LC50 values (1.789 and $0.82 \mathrm{ppm}$ ) at the field strain were significantly higher than that at the parental strain (1.405 and $0.073 \mathrm{ppm}$ ), $\mathrm{P}<0.05$ (table 1). On the other hand, for the B.t. H14 the LC50values which were $2.550 \mathrm{ppm}$ and $2.491 \mathrm{ppm}$ for both the field and laboratory strain respectively did not differ significantly $(\mathrm{P}>0.05)$. For each of the two insecticides the slope decreased in the pure parental laboratory colony more than in the field strain.

The parental laboratory colony larvae subjected to laboratory selection for 12 generations at LC50 values for successive generations. 
It is evident (tab. 1), that the LC50 values, in ppm, of methomyl and malathion treated generations progressed significantly $(\mathrm{P}<0.05)$ by generations from 1.405 and $0.073 \mathrm{ppm}$ at F0 to reach 8.925 and $0.156 \mathrm{ppm}$ at F12.

Slope of all the successive generations decreased gradually than that of the parental generation (table 1). The LC50 values of both methomyl and malathion showed the highest susceptibility levels at the parental generation (F0), while the lowest level was at F12. However, the LC50 values in biological insecticides did not differ significantly $(\mathrm{P}>0.05)$.

In biological insecticides, the real decrease in the slope values appear obviously from F4 to F12 (1.239 to 1.154).

Table 1: Susceptibility of 3rd instar Cx. pipiens larvae against methomyl, malathion and B.t. H14 insecticides.

\begin{tabular}{|l|c|c|c|c|c|c|}
\hline \multirow{2}{*}{$\begin{array}{l}\text { Genera- } \\
\text { tion }\end{array}$} & \multicolumn{2}{|c|}{ Methomyl } & \multicolumn{2}{|c|}{ Malathion } & \multicolumn{2}{|c|}{ B. $t$. H14 } \\
\cline { 2 - 7 } & $\mathrm{LC}_{50}$ ( C.1.)* & Slope & $\mathrm{LC}_{50}(\mathrm{C} .1 .)^{*}$ & Slope & LC $_{50}$ ( C.I.) & Slope \\
\hline Field & $\begin{array}{c}1.789 \\
(1.63-1.963)\end{array}$ & 1.655 & $\begin{array}{c}0.082 \\
(0.078-0.09)\end{array}$ & 1.379 & $\begin{array}{c}2.550 \\
(2.44-2.661)\end{array}$ & 1.452 \\
\hline $\mathrm{F}_{0}$ & $\begin{array}{c}1.405 \\
(1.30-1.515)\end{array}$ & 1.460 & $\begin{array}{c}0.073 \\
(0.07-0.075)\end{array}$ & 1.251 & $\begin{array}{c}2.491 \\
(2.40-2.583)\end{array}$ & 1.210 \\
\hline $\mathrm{F}_{2}$ & $\begin{array}{c}3.982 \\
(3.94-4.024)\end{array}$ & 1.061 & $\begin{array}{c}0.138 \\
(0.129-0.15)\end{array}$ & 1.222 & $\begin{array}{c}2.432 \\
(2.365-2.5)\end{array}$ & 1.177 \\
\hline $\mathrm{F}_{4}$ & $\begin{array}{c}6.260 \\
(6.13-6.389)\end{array}$ & 1.170 & $\begin{array}{c}0.146 \\
(0.14-0.147)\end{array}$ & 1.074 & $\begin{array}{c}2.428 \\
(2.34-2.515)\end{array}$ & 1.239 \\
\hline $\mathrm{F}_{8}$ & $\begin{array}{c}8.135 \\
(8.087-8.18)\end{array}$ & 1.044 & $\begin{array}{c}0.152 \\
(0.15-0.154)\end{array}$ & 1.078 & $\begin{array}{c}2.422 \\
(2.375-2.47)\end{array}$ & 1.175 \\
\hline $\mathrm{F}_{12}$ & $\begin{array}{c}8.925 \\
(8.818-9.03)\end{array}$ & 1.075 & $\begin{array}{c}0.156 \\
(0.15-0.158)\end{array}$ & 1.180 & $\begin{array}{c}2.395 \\
(2.339-2.45)\end{array}$ & 1.154 \\
\hline
\end{tabular}

$\bullet$ Changes in protein content in Cx. pipiens resistant colonies selected by methomyl, malathion and B. $t$. H14.

Changes in protein contents $(\mathrm{mg} / \mathrm{ml})$ in parental laboratory control colony (F0) were compared with those of the field strain after $24 \mathrm{~h}$ exposure to chemical insecticides (methomyl, malathion) and after $48 \mathrm{~h}$ exposure to biological insecticides (B. t. H14). As illustrated in (table 2), the protein contents of the field strain $(0.298 \pm 0.0006 \mathrm{mg} / \mathrm{ml}$ and $0.2991 \pm 0.0016 \mathrm{mg} / \mathrm{ml})$ were significantly higher $(\mathrm{p}<0.05)$ than those of the F0 before $(0.2967 \pm 0.0009 \mathrm{mg} / \mathrm{ml})$ and after treatment with methomyl (0.2973$\pm 0.0015 \mathrm{mg} / \mathrm{ml}$ ).

On the other hand, there were no significant differences $(p>0.05)$ between the protein contents of the field strain and F0 after the exposure either to malathion or B. t. H14. Significant increases $(p<0.05)$ in protein content were recorded (Tab. 2) in methomyl selected larvae from F12 to F20 compared to the control larvae. The protein contents ranged from $(0.299 \pm 0.001 \mathrm{mg} / \mathrm{ml})$ at $\mathrm{F} 12$ and $(0.313 \pm 0.011 \mathrm{mg} / \mathrm{ml})$ at F20.

On the other hand, in malathion selected larvae significant decreases $(\mathrm{P}<0.05)$ in protein content were recorded from F0 $(0.293 \pm 0.003 \mathrm{mg} / \mathrm{ml})$ to F16 $(0.293 \pm 0.002 \mathrm{mg} / \mathrm{ml})$ when compared with control mosquito. The decrease extended to F20 (0.294 \pm 0.003 $\mathrm{mg} / \mathrm{ml}$ ) when compared to methomyl resistance larvae. 
Table 2: Changes of protein content $(\mathrm{mg} / \mathrm{ml})$ in control colony compared with Methomyl, Malathion and B.t. H14 resistance colony.

\begin{tabular}{|l|l|l|l|l|}
\hline Generation & $\begin{array}{l}\text { Control laboratory } \\
\text { susceptible colony }\end{array}$ & $\begin{array}{l}\text { Methomyl re- } \\
\text { sistance colony }\end{array}$ & $\begin{array}{l}\text { Malathion re- } \\
\text { sistance colony }\end{array}$ & $\begin{array}{l}\text { B.t.H14 resis- } \\
\text { tance colony }\end{array}$ \\
\hline Field & $0.298 \pm 0.001^{*}$ & $0.299 \pm 0.002^{*}$ & $0.293 \pm 0.0023$ & $0.297 \pm 0.001$ \\
\hline $\mathrm{F}_{0}$ & $0.297 \pm 0.001$ & $0.297 \pm 0.002$ & ${ }^{\#} 0.293 \pm 0.003^{*}$ & $0.297 \pm 0.001$ \\
\hline $\mathrm{F}_{2}$ & $0.296 \pm 0.002$ & $0.297 \pm 0.001$ & ${ }^{\#} 0.292 \pm 0.001^{*}$ & $0.296 \pm 0.001$ \\
\hline $\mathrm{F}_{4}$ & $0.296 \pm 0.002$ & $0.297 \pm 0.004$ & ${ }^{\#} 0.291 \pm 0.001^{*}$ & $0.295 \pm 0.002$ \\
\hline $\mathrm{F}_{8}$ & $0.296 \pm 0.002$ & $0.298 \pm 0.002$ & ${ }^{\#} 0.291 \pm 0.001^{*}$ & $0.291 \pm 0.003^{\mathrm{a}}$ \\
\hline $\mathrm{F}_{12}$ & $0.297 \pm 0.002$ & $0.299 \pm 0.001^{*}$ & ${ }^{\#} 0.292 \pm 0.004^{*}$ & $0.290 \pm 0.001^{\mathrm{a}}$ \\
\hline
\end{tabular}

Each point represent means \pm SD and $(n=10)$. *Significant $P<0.05$ (compare between control laboratory susceptible colony with methomyl, malathion \& B.t. H14 resistance colonies. \#Significant $\mathrm{P}<0.05$ (compare between methomyl \& malathion resistance colony, $\bullet$ Changes in trypsin activity in resistant colonies selected by methomyl, malathion and B. $t$. H14.

For methomyl resistance colony, the trypsin-like activity was $(19.419 \pm 0.431$ $\mu \mathrm{mol} / \mathrm{min} / \mathrm{mg}$ protein) at F0 then declined gradually to form a trough at F8 (15.616 $\pm 0.408 \mu \mathrm{mol} / \mathrm{min} / \mathrm{mg}$ protein) then, increased gradually to maximum peak at F12 $(17.734 \pm 0.452 \mu \mathrm{mol} / \mathrm{min} /$ mg protein, $\mathrm{P}<0.05)$. At all generations the trypsin activity levels of methomyl selected colony were significantly lower $(\mathrm{P}<0.05)$ than controls. In malathion selected colony, trypsin specific activity was significantly lower than in 12 generations controls $(\mathrm{P}<0.0001)$. Trypsin-like activity formed a trough at F4 $(10.810 \pm 0.860 \mu \mathrm{mol} / \mathrm{min} / \mathrm{mg}$ protein) followed by a gradual increase to a value of $(12.423 \pm 1.014 \mu \mathrm{mol} / \mathrm{min} / \mathrm{mg}$ Table 3: Trypsin activity ( $\mu \mathrm{mol} / \mathrm{min} / \mathrm{mg}$ protein) in methomyl, malathion and $B . t$. H14 in Cx. pipiens selected larvae in compared to laboratory susceptible control colony.

\begin{tabular}{|l|l|l|l|l|}
\hline $\begin{array}{l}\text { Generation } \\
\text { time }\end{array}$ & $\begin{array}{l}\text { Control laboratory } \\
\text { susceptible colony }\end{array}$ & $\begin{array}{l}\text { Methomyl re- } \\
\text { sistance colony }\end{array}$ & $\begin{array}{l}\text { Malathion re- } \\
\text { sistance colony }\end{array}$ & $\begin{array}{l}B . t \text {. H14 resist- } \\
\text { ance colony }\end{array}$ \\
\hline Field & $19.405 \pm 0.29^{*}$ & $18.574 \pm 0.36^{*}$ & $13.27 \pm 0.52^{*}$ & $9.631 \pm 0.38$ \\
\hline F0 & $20.863 \pm 0.545$ & $19.419 \pm 0.431^{*}$ & ${ }^{\#} 14.640 \pm 0.782^{*}$ & $9.481 \pm 0.876^{\mathrm{a}}$ \\
\hline F2 & $20.814 \pm 0.626$ & $18.303 \pm 0.446^{*}$ & ${ }^{\#} 12.412 \pm 0.532^{*}$ & $9.511 \pm 1.298^{\mathrm{a}}$ \\
\hline F4 & $20.799 \pm 0.578$ & $16.946 \pm 0.673^{*}$ & ${ }^{\#} 10.810 \pm 0.860^{*}$ & $9.207 \pm 0.581^{\mathrm{a}}$ \\
\hline F8 & $20.846 \pm 0.581$ & $15.616 \pm 0.408^{*}$ & ${ }^{\#} 11.796 \pm 0.756^{*}$ & $4.172 \pm 0.880^{\mathrm{a}}$ \\
\hline F12 & $20.806 \pm 0.452$ & $17.734 \pm 0.452^{*}$ & ${ }^{\#} 12.423 \pm 1.014^{*}$ & $2.097 \pm 0.587^{\mathrm{a}}$ \\
\hline
\end{tabular}

Each point represent means \pm SD and $(n=10)$. ${ }^{*}$ Significant (compare between control laboratory susceptible colony with methomyl \& malathion resistance colonies) \# Significant (compare between methomyl \& malathion resistance colonies) ${ }^{\mathrm{a}}$ : significant $(P<0.05)$ when compare control laboratory susceptible colony to $B$. $t$. H14 resistance. $\bullet$ Changes in aminopeptidase activity in resistant colonies selected by methomyl, malathion and B. $t$. H14. protein) at F12. In all generations, specific activity of trypsin-like enzyme was significantly lower $(\mathrm{p}<0.0001)$ in malathion resistant colony than in methomyl resistant one.

In $B . t$. H14 pressed larvae comparable levels of trypsin activity were recorded at generations $\mathrm{F}_{0}, \mathrm{~F}_{2}$ and $\mathrm{F}_{4}$ then, activity suffered a gradual decreased to minimum levels at $\mathrm{F}_{12}(2.097 \pm 0.587$ $\mu \mathrm{mol} / \mathrm{min} / \mathrm{mg}$ protein $)(\mathrm{P}<0.05)$. On the other hand at all the tested generations the levels of trypsin activity were significantly lower $(\mathrm{P}<0.0001)$ than in susceptible control laboratory colony, malathion, methomyl and B. $t$. H14 resistance colonies. 
Comparable levels of aminopeptidase activity $(\mathrm{P}>0.05)$ were recorded in $\mathrm{F}_{0}$ of methomyl $(133.821 \pm 5.326 \mu \mathrm{mol} /$ $\mathrm{min} / \mathrm{mg}$ protein), malathion (135.488 $\pm 6.651 \mu \mathrm{mol} / \mathrm{min} / \mathrm{mg}$ protein) and B.t. H14 $(143.978 \pm 3.789 \mu \mathrm{mol} / \mathrm{min} / \mathrm{mg}$ protein) resistant colonies compared to the field strain. On the other hand, significantly higher enzyme activity was recorded at $\mathrm{F}_{0}(178.354 \pm 2.6639 \mu \mathrm{mol} / \mathrm{min}$ $/ \mathrm{mg}$ protein) compared to the field strain $(\mathrm{P}=0.004)$.

In methomyl pressed larvae, aminopeptidase activity level was (133.821 $\pm 5.320 \mu \mathrm{mol} / \mathrm{min} / \mathrm{mg}$ protein) at $\mathrm{F}_{0}$ then it fluctuated throughout the following generations to form troughs at $\mathrm{F}_{2}(126.863 \pm 5.7263 \mu \mathrm{mol} / \mathrm{min} / \mathrm{mg}$ protein), $F_{12}(145.145 \pm 4.118 \mu \mathrm{mol} / \mathrm{min} / \mathrm{mg}$ protein) and a peak at $\mathrm{F}_{8}(160.176 \pm$ $2.783 \mu \mathrm{mol} / \mathrm{min} / \mathrm{mg}$ protein), $\mathrm{P}<0.05$.
However, at all the tested generations the levels of aminopeptidase activity were significantly lower $(\mathrm{P}<0.05)$ than in control susceptible colony.

In malathion selected larvae, comparable levels of aminopeptidase activity were recorded at $\mathrm{F}_{0}, \mathrm{~F}_{2}, \mathrm{~F}_{4}(\mathrm{P}>0.05)$ then activity increased gradually to reach maximum level at $F_{12}(152.497$ $\pm 6.775 \mu \mathrm{mol} / \mathrm{min} / \mathrm{mg}$ protein, $\mathrm{P}<0.05$ ).

In B. t. H14 pressed larvae comparable levels of aminopeptidase activity were recorded at F0 and F2 then a gradual decline in activity was recorded to reach the minimum level at F12 $(102.035 \pm 3.580 \mu \mathrm{mol} / \mathrm{min} / \mathrm{mg}$ protein, $\mathrm{P}<0.0001)$. On the other hand, at all the tested generations the levels of aminopeptidase activity were significantly lower $(\mathrm{P}<0.05)$ than in control susceptible colony.

Table 4: Aminopeptidase specific activity $(\mu \mathrm{mol} / \mathrm{min} / \mathrm{mg}$ protein) in Cx. pipiens resistance larvae in methomyl and malathion compared to laboratory susceptible control colony.

\begin{tabular}{|l|c|c|c|c|}
\hline $\begin{array}{c}\text { Generation } \\
\text { time }\end{array}$ & $\begin{array}{c}\text { Control laboratory } \\
\text { susceptible colony }\end{array}$ & $\begin{array}{c}\text { Methomyl resistance } \\
\text { colony }\end{array}$ & $\begin{array}{c}\text { Malathion re- } \\
\text { sistance colony }\end{array}$ & $\begin{array}{c}\text { B.t. H14 resist- } \\
\text { ance colony }\end{array}$ \\
\hline Field & $173.05 \pm 1.31^{*}$ & $134.91 \pm 0.72$ & $138.97 \pm 0.8$ & $141.03 \pm 1.296$ \\
\hline $\mathrm{F}_{0}$ & $178.35 \pm 2.66$ & $133.82 \pm 5.3^{*}$ & $135.488 \pm 6.65^{*}$ & $143.98 \pm 3.79^{\mathrm{a}}$ \\
\hline $\mathrm{F}_{2}$ & $178.77 \pm 2.57$ & $126.86 \pm 5.73^{*}$ & ${ }^{\sharp} 142.195 \pm 3.60^{*}$ & $140.92 \pm 3.43^{\mathrm{a}}$ \\
\hline $\mathrm{F}_{4}$ & $179.18 \pm 2.14$ & $144.96 \pm 9.83^{*}$ & $138.662 \pm 7.61^{*}$ & $131.48 \pm 2.99^{\mathrm{a}}$ \\
\hline $\mathrm{F}_{8}$ & $179.34 \pm 2.35$ & $160.18 \pm 2.78^{*}$ & ${ }^{\sharp} 149.466 \pm 7.51^{*}$ & $110.38 \pm 1.37^{\mathrm{a}}$ \\
\hline $\mathrm{F}_{12}$ & $177.32 \pm 3.11$ & $145.15 \pm 4.12^{*}$ & $152.497 \pm 6.775^{*}$ & $102.04 \pm 3.58^{\mathrm{a}}$ \\
\hline
\end{tabular}

Each point represent means \pm SD and $(n=10) . *$ Significant (compare between control laboratory susceptible colony with methomyl \& malathion resistance colonies). \#Significant (compare between methomyl \& malathion resistance colonies). ${ }^{a}$ : significant $(P<0.05)$ when compare control laboratory susceptible colony to $B . t$. H14 resistance colony.

\section{Discussion}

Bioassay: Dose response relationships were determined for malathion, and methomyl in both field mosquito larvae and parental laboratory colony. The examined laboratory colony was more susceptible to the methomyl $\left(\mathrm{LC}_{50}=1.405 \mathrm{ppm}\right)$ and the malathion
$\left(\mathrm{LC}_{50}=0.073 \mathrm{ppm}\right)$ than the field strain $\left(\mathrm{LC}_{50}=1.789 \mathrm{ppm}\right.$ and $0.082 \mathrm{ppm}$ for the methomyl and malathion, respectively. The slopes of the mortality lines were lower in the pure parental laboratory colony than in field mosquito larvae. This explain the homogeneity occur in the mosquito larvae laboratory colony 
(pure colony). It was evident that the highest relative toxicity, based on $\mathrm{LC}_{50}$ values was at $(\mathrm{F} 0)$ then toxicity response decreased progressively as the generations proceeded $\left(\mathrm{LC}_{50}\right.$ values increased). In other words, the sensitivity of mosquito larvae toward both methomyl and malathion decreased as the generations succeeded.

For methomyl, the $\mathrm{LC}_{50}$ values increased from $1.405 \mathrm{ppm}$ at F0 to reach $8.925 \mathrm{ppm}$ at F12. For malathion, the $\mathrm{LC}_{50}$ values were $0.073 \mathrm{ppm}$ at $\mathrm{F} 0$ and increased to reach $0.156 \mathrm{ppm}$ at F12. The $\mathrm{LC}_{50}$ values increased among succession of generations irrespective of the used chemical insecticide.

The progressive tolerance or resistance to the chemical insecticide increased with succeeding generations of exposure during the process selection. Similar data were recorded for fenitrothion (Hamed et al, 1991), deltamethrin (Chareonviriya-phap et al, 2003) and for malathion and permethrin (Selvi et al, 2005) they found that selection pressure was important for maintaining resistance in larval populations.

The slope function of the Id-p lines was taken as an indication of the degree of homogeneity of the population in its response to a toxicant. For each of the two used insecticides, it is evident that the F12 slope was the steepest and tended to be located at the right side of the figure, while F0 line clung to the left side. The slopes values coincided with such observation, the higher; the $\mathrm{LC}_{50}$ value the flatter was the slope. In developing the resistance it would be expected that the slope would decline with progressive selection as a result of the appearance of heterozygotes (SR) and phenotypes in the population. This data agreed with other authors (Georghiou and Hawley, 1971; Hamed et al, 1991).

The present results revealed no significant difference in the $\mathrm{LC}_{50}$ values of $B$. $t$. H14 on mosquito larvae along the twelve successive generations, i.e. the mosquitoes showed marked stability in their susceptibility and their resistance ratios to this biological insecticide. This agreed with Saleh et al. (2003) who detected that the beginning of resistance after $\mathrm{F}_{15}$ in $C x$. pipiens. The $\mathrm{LC}_{50}$ were higher than the values previously reported (Rodcharoen and Mulla, 1996; Chevillon et al, 2001; Wirth et al, 2001). This was not unusual because toxicity of biological insecticides can be quite variable from one laboratory to another (Paul et al, 2005).

In the present study, the protein is the most obvious nutrient in the meal of mosquitoes and trypsin-like enzyme is evidently the major protease in mosquitoes (Briegel and Lea, 1975) responsible for the initial breakdown of proteins and large peptides. The secondary digestion of peptides is brought about by aminopeptidase (Billingsley and Hecker, 1991). The present results showed a significant higher increase in trypsin activity in methomyl resistance colony compared to that of malathion selected one. The increase in proteolytic activity was accompanied by an increase in protein content. In B. $t$. H14 resistance colony, the decrease in trypsin and aminopeptidase activities were accompanied by decrease in the protein content. 
On the other hand, in susceptible control colony (pure from any insecticides) both the proteolytic activity and the protein content were significantly higher than those in the insecticides selected populations. Consequently, it could be concluded that presence of organophosphate, carbamate and biological insecticides may probably induce an inhibitory effect on the proteolytic activity in insecticide selected populations. Generally, the changes in both protein content and proteolytic activities are dependent.

The present results differed from Chareonviriyaphap et al. (2003) who found no significant difference in the total protein content among the susceptible control and the 6 generations of Anopheles minimus exposed to deltamethrin (Pyrethroid) $(\mathrm{P}>0.05)$ despite different levels of resistance. Parallel to the present results, previous study on Ae. aegypti found low significant difference in the total protein content among the 5 populations of adult mosquitoes collected from Bangkok and Pathum Thani exposed to deltamethrin $(P<0.05)$ when compared to control (Yaicharoen et al, 2005). Bahgat et al. (2003) recorded significantly low protein content in $C x$. pipiens fed on soybean trypsin inhibitor (SBTI) that act as competitive inhibitor for trypsin activity.

In this study, the change in enzyme concentration or quantity as a direct response of change caused by resistance formation may effect on protein concentration. Enzyme is a protein in nature when decrease enzyme activity according to that, decrease protein content in whole larvae. This result disagreed with Yaicharoen et al. (2005) who found that the activity of enzyme increase in resistant population and the protein content decrease than control.

\section{Enzymatic assay:}

In both methomyl and malathion selected colonies, the present results showed a significant decrease in trypsin activity at almost all the pressed generations compared with the control susceptible larvae, i.e. the rate of insecticides hydrolysis by trypsin remained significantly lower in the treated larvae compared with the control. However, a significant increase in activity appeared from $F_{8}$ to $F_{12}$ in methomyl selected colony and from $F_{4}$ to $F_{12}$ in malathion selected colony. This may be an early indication of the development of resistance in the future generations (after $\mathrm{F}_{12}$ ). Yang et al. (2008) mentioned that trypsin which is a member of serine proteases superfamily have a catalytic triad of serine, histidine and aspartate within the binding pocket which hydrolysis peptides and ester bond. The same author reported that the seine protease gene NYD-Tr could hydrolysis the chemical insecticides deltamethrin to metabolic product with much lower toxicity. As resistance is a multigenic phenomenon systematic study to characterize the enzyme involved in hydrolysis of carbamate (methomyl) and organophosphate (malathion) are still lacking.

Shen et al. (2002) found that the expression of trypsin gene was significantly higher in deltamethrin resistant $C x$. pipiens strain than in the susceptible strain. Gong et al. (2005) reported 
that two serine proteinase genes from $C x$. pipiens were found to be expressed at significantly higher level in the resistant strain than in the susceptible one.

Parallel to the trypsin result, there was a significant decrease in aminopeptidase activity at all the pressed generations by malathion and methomyl compared with the control larvae. On the other hand, Aminopeptidase activity increased gradually in the pressed larvae to reach its maximum level at $F_{12}$. The increase in activity may be an indication of the development of resistance. In a study on Musca domestica Wilkins et al. (1999) found that the untreated fentrothion resistance insect had significantly higher protease level than the susceptible strain. They found further increase in protease activity prior to insecticide exposure in both strain. They speculated that the increase in proteolytic activity in the resistance strain resulted in increased supply of amino acids prior to denovo synthesis of detoxifying enzymes following insecticide exposure. Ahmed et al. (1998) determined the proteolytic activity in a DDT resistant and susceptible strain of $M$. demestica. The resistant strain showed significantly higher protease activity compared to the susceptible strains. The authors suggested the involvement of proteolytic enzymes in the induction of detoxifying enzymes, thus indicating a possible role of the intracellular proteolytic activities in the resistance mechanisms.

In the present study, B. $t$. H14 pressed larvae at all the tested generations the levels of both Aminopeptidase and trypsin activities were significantly lower than control susceptible larvae. On the other hand, the levels of enzymes activities decreased gradually to reach their minimum levels at $F_{10}$. The present results agreed with $\mathrm{Li}$ et al (2004) on Ostrinia nubilalis reporting significantly lower proteinase activity in B.t.-resistant larvae than for those of the susceptible larvae. These results were corroborated by decreased temporal activation of cryl $\mathrm{Ab}$ protoxin with soluble proteinases from the resistant strain when compared to that of susceptible strain. One hypothesis is that reduced protoxin processing by decrease Trypsin like activity is important in enhancing the insects' capacity to withstand larger B.t. protoxin doses and thus provides a survival advantage. Oppert et al. (1997) stated the resistance may be due to lacking a major gut proteinase involved in activation of B.t. protoxin. The present data agreed with reported data on Trypsinlike proteinase activity using Kinetic analysis (Huang et al, 1999).

Gilliland et al. (2002) reported that aminopeptidase activities in neonates and third instar larvae of Manduca sexta, Pieris brassicae, Mamestra brassica, and Agrotis ipsilon were inversely correlated with increased resistance during larval development i.e. Aminopeptidase activity decreases with the increase in resistance, which agree with the present results. Oppert et al. (1994) linked the resistance in Bt-resistance strain to the fifth fold decrease in the proteolytic activity compared to susceptible strain; they reported that the 
resistant strain did process protoxin at a slower rate than the parental susceptible strain. Candas et al. (2003) found that proteomic comparison of B.t.susceptible and resistance strain provide evidence that proteinase-mediated resistance was associated with multiple protein alterations related to increased oxidative metabolism.

So, any change in insect gut physiology that affects one or more steps in the process of activation of protoxins including solubilization and hydrolysis by gut proteinases could prevent toxicity and lead to the development of resistant pest populations (Li et al, 2004). The recorded changes in the activity of trypsin and aminopeptidase could be used as indications of the multiple previous uses of these insecticides in the field.

\section{Conclusion}

The outcome results showed that the environmental friend Bacillus thuringiensis (B. t. H14) proved more safe and effective against Culex pipiens larvae. The changes recorded in the enzymes activities could be used as useful tools to detect for multiple previous uses of these chemical and biological insecticides in the field.

\section{References}

Ahmed, S, Wilkins, RM, Mantle, D, 1998: Comparison of proteolytic enzyme activities in adults of insecticide resistant and susceptible strains of the housefly Musca domestica L. Insect Biochem. Mol. Biol. 28, 9:629-39.

Bahgat, IM, Kamel, NH, Saleh, NA K, 2003: Post feeding proteolytic activity of trypsin and Aminopeptidase in the midgut of female Culex pipiens $\mathrm{L}$. (Diptera: Culicidae) Bull. Entomol. Soc. Egypt 80:23-36.

Bahgat, MM, Saad, AH, El-Shahawi, GA, Gad, AM, Ramzy, RM, et al, 2011: Cross-reaction of antigen preparations from adult and larval stages of the parasite Setaria equina with sera from infected humans with Wuchereria bancrofti. East. Mediterr. Hlth. J. 17, 8: 679-86.

Billingsley, PF, Hecker, H, 1991: Blood digestion in the mosquito, Anopheles stephensi L. (Diptera: Culicidae): Activity and distribution of trysin, amino-peptidase, and $\alpha$-glucosidase in the midgut. J. Med. Entomol. 28, 6:865-71.

Bradford, MM, 1976: A rapid and sensitive method for the quantities of protein utilizing the principle of protein dye binding. Anal. Biochem. 72:24854.

Briegel, H, Lea, AO, 1975: Relationship between protein and proteplytic activity in the midgut of mosquitoes $\mathrm{J}$. Insect Physiol. 21:1597-604.

Brooke, BD, Richard, HH, Lizette, L K, Dossou-Yovo, J, Maureen, C, 1999: Evaluation of polymerase chain reaction assay for detection of pyrethroid insecticide resistance in a malaria vector species of Anopheles gambiae complex. J. Am. Mosq. Cont. Assoc. 15:565-8.

Candas, M, Loseva, O, Oppert, B, Kosaraju, P, Bulla, JrLA, 2003: Insect resistance to Bacillus thuringiensis: Alterations in the Indian meal moth larval gut proteome. Mol. Cell. Prot. 2: 19-28. 
Chareonviriyaphap, T, Rongnoparut, P, Chantarumporn, P, Bangs, $M$ J, 2003: Biochemical detection of pyrethroid resistance mechanisms in Anopheles minimus in Thailand. J. Vect. Ecol., 28:108-16.

Chevillon, C, Bernard, C, Marquine, M, Pasteur, N, 2001: Resistance to Bacillus sphaericus in Culex pipiens (Diptera: Culicidae) interaction between recessive mutants and evolution in southern France. J. Med. Entomol. 38:657-64

Dillon, RJ, Lane, RP, 1993: Blood meal digestion in the midgut of Phlebotomus papastasi and Phlebotomus langeroni. Med. Vet. Entomol. 7:22532.

El-Bahnasawy, MM, Khater, MM Kh, Morsy, TA, 2013: The mosquito borne west Nile virus infection: Is it threating to Egypt or a neglected endemic disease? J. Egypt. Soc. Parasitol. 43, 1:87-102.

Georghiou, GP, Hawley, MK, 1971: Insecticide resistance resulting from sequential selection of houseflies in the field by organophosphorus compounds. Bull. WHO 45:43-51.

Gilliland, A, Chambers, CE, Bone, E J, Ellar, DJ, 2002: Role of Bacillus thuringiensis Cryl delta endotoxin binding in determining potency during lepidopteran larval development. Appl. Environ. Microbiol. 68:1509-15.

Gong, MQ, Shen, B, Gu, Y, Tian, $H$ S, Ma, L, et al, 2005: Serine proteinase over-expression in relation to deltamethrin resistance in Culex pipiens Pallens. Arch. Biochem. Biophys. 438:5362
Hamed, MS, Shoukry, A, Said, MA, Kenawy, MA, Gad, AM, et al, 1991: Selection for fentrothion-resistance in Culex pipiens L. larvae (Diptera: $\mathrm{Cu}-$ licidae) J. Egyptian Society Parasitol. 21, 1:243-51.

Hanafi, HA, Fryauff, DJ, Saad, MD, Soliman, AK, Mohareb, EW, et al, 2011: Virus isolations and high population density implicate Culex antennatus (Becker) (Diptera: Culicidae) as a vector of Rift Valley Fever virus during an outbreak in the Nile Delta of Egypt. Acta Trop. 119, 2/3:119-24.

Harbach, RE, 1988: The mosquitoes of the subgenus Culex in South Western Asia and Egypt (Diptera: Culicidae). Amer. Entomol. Inst. 24, 1:1-240.

Hemingway, J, Karunaratne, SH, 1998: Mosquito carboxylesterases: A review of the molecular biology and biochemistry of a major insecticide resistance mechanism. J. Med. Vet. Entomol. 12:1-12.

Huang, F, Zhu, KY, Buschman, LL, Higgins, RA, Oppert, B, 1999: Comparison of midgut proteinases in Bacillus thuringensis-susceptible and resistant European corn borer, Ostrinia nubilalis (Lepidoptera: Pyralidae). Pest. Biochem. Physiol., 65: 132-9.

Li, H, Oppert, B, Higgins, RA, Huang, F, Zhu, KY, et al, 2004: Comparative analysis of proteinase activities of Bacillus thuringiensis-resistant and susceptible Ostrinia nubilalis (Lepidoptera: Crambidae). Insect Biochem. Mol. Biol. 34, 8:753-62.

Martinez-Torres, D, Chandre, F, Williamson, MS, Darriet, F, Serge, JB, Devonshire, AL, et al, 1998: Molecu- 
lar characterization of pyrethroid knockdown resistance $(\mathrm{kdr})$ in the major malaria vector Anopheles gambiae. Insect Molec. Biol. 7:179-84

Mikhail, MW, Al-Bursheed, KhM, Abd El-Halim, AS, Morsy, TA, 2009: Studies on mosquito borne diseases in Egypt and Qatar. J. Egypt. Soc. Parasitol. 39, 3:745-56.

Morsy, TA, 2012: Insect bites and what is eating you? J. Egypt. Soc. Parasitol. 42, 2:291-308.

Mostafa, AA, Allam, KA, 2001: Studies on the present status of insecticides resistance on mosquitoes using the diagnostic dosages in El-Fayium Governorate, a spot area of malaria in Egypt. J. Egypt. Soc. Parasitol. 31, 1:177-86.

Oppert, B, Kramer, KJ, Beeman, R W, Johnson, DE, McGaughey, WH, 1997: Proteinase-mediated insect resistance to Bacillus thuringiensis toxins. J. Biol. Chem. 272:23473-6.

Oppert, B, Kramer, KJ, Johnson, D E, MacIntosh, SC, McGaughey, WH, 1994: Altered protoxin activation by midgut enzymes from a Bacillus thuringiensis resistant strain of Plodia interpunctella. Biochem. Biophys. Res. Commun. 198:940-7.

Paul, A, Harrington, LC, Zhang, L, Scott, JG, 2005: Insecticide resistance in Culex pipiens from New York. J. Am. Mosq. Control Assoc. 21, 3:305-9.

Ramasamy, MS, Kulasekera, R, Sikrishnaraj, KA, Ramasamy, R, 1996: Different effects of modulation of mosquito (Diptera: Culicidae) trypsin activity on the infectivity of two human malaria (Hemosporidia: Plasmodidae) parasites. J. Med. Entomol. 33, 5:77782.

Riehle, A, Jacobs-Lorena, M, 2005: Using bacteria to express and display anti-parasite molecules in mosquitoes: current and future strategies. Insect Biochem. Mol. Biol. 35: 699-707.

Rodcharoen, J, Mulla, MS, 1996: Cross resistance to $B$. sphaericus strains in Cx. quinquefasciatus. J. Am. Mosq. Cont. Assoc. 12, 2:247-50.

Rodcharoen, J, Mulla, MS, 1994: Resistance development in Culex quinquefasciatus (Diptera: Culicidae) to the microbial agent Bacillus sphaericus. J. Econ. Entomol. 87:1133-40.

Saleh MS, El-Meniawi FA, Kelada N L, Zahran, HM, 2003: Resistance development in mosquito larvae Culex pipiens to the bacterial agent Bacillus thuringiensis var. israelensis. J. App. Entomol. 127, 1:29-32.

Selvi, S, Edah, MA, Nazni, WA, Lee, HL, Azahari, AH, 2005: Resistance development and insecticide susceptibility in Culex quinquefasciatus against selection pressure of Malathion and permethrin and its relationship to crossresistance towards propoxur. Trop. Biomed. 22:103-13.

Shen, B, Tian, HS, Ma, L, Li, XL, Zhen, SZ, et al, 2002: Cloning and sequence analysis of full-length trypsin cDNA of Culex pipiens Pallens. Sheng $\mathrm{Wu}$ Hua Xue Yu Sheng Wu Wu Li Xue Bao (Shanghai), 34, 1:28-32.

Shoukry, A, Hamed, MS, Said, MA, Gad, AM, Kenawy, M.A, et al, 1990: The mode of inheritance of fenitrothion resistance in Culex pipiens L. larvae 
(Diptera: Culicidae) J. Egypt. Soc. Parasitol. 20:683-9.

Spector, T, 1978: Refinement of the Coomassie Blue method of protein quantitation Anal. Biochem. 86:142-6.

Timmermann, SE, Briegel, H, 1993: Water depth and larval density affect development and accumulation of reserves in laboratory populations of mosquitoes. Bull. Soc. Vector Ecol. 18: 178-87

WHO, 1981: Instructions for Determining the Susceptibility or Resistance of Larval Mosquitoes to Insecticides; the Mimeographed Document/VBC/81. 811 Geneva.

Wilkins, RM, Ahmed, S, Mantle, D, 1999: Comparative effect of fenitrothion treatment on intracellular protease activities in insecticide-resistant and susceptible strains of Musca domestica
L. Comp. Biochem. Physiol. Pharmacol. Toxicol. Endocrinol. 124, 3:337-43.

Wirth, MC, Delécluse, A, Walton, W E, (2001: Cyt1Ab1 and Cyt2Ba1 from Bacillus thuringiensis subsp. Medellin and Bacillus thuringiensis subsp. israelensis synergize Bacillus sphaericus against Aedes aegypti and resistant $\mathrm{Cu}$ lex quinquefasciatus (Diptera: Culicidae). J Inverteb. Pathol 82:133-5

Yaicharoen, R, Kiatfuengfoo, R, Chareonviriyaphap, $T$, Rongnoparut, $P$, 2005: Characterization of deltamethrin resistance in field populations of Aedes aegypti in Thailand. J. Vect. Ecol. 30, 1:144-50

Yang, Q, Zhou, D, Sun, L, Zhang, D, Qian, J, et al, 2008: Expression and characterization of two pesticide resistance-associated serine protease genes (NYD-tr and NYD-ch) from Culex pipiens Pallens for metabolism of deltamethrin. Parasitol. Res. 103, 3:507-16. 